УДК 261

DOI 10.35423/2078-8142.2020.1.11

Дмитро Франків, ієромонах; аспірант кафедри богослов'я та релігієзнавства Національного педагогічного університету імені М. П. Драгоманова м. Київ, Украӥна e-mail: ieromonahdmytro@gmail.com ORCID: https://orcid.org/0000-0002-2342-0951

\title{
БОГОСЛОВСЬКИЙ АНАЛІЗ ПРИНЦИПУ ТАЛІОНУ ТА ЙОГО КОРЕЛЯЦІЯ $З$ ВИХІДНИМ ПРИНЦИПОМ ФОРМУВАННЯ ЄВРЕЙСЬКОГО ПРАВА В БІБЛІЙНУ ЕПОХУ
}

Метою даної статті стало дослідження принципу Таліону як основного принципу дії єврейського права. Для иього було використано абстрактно-логічні методи, історико-правовий, феноменологічний, аксіологічний, гносеологічний методи, метод критичного та системного аналізу, метод компаративної теології. У результаті дослідження було богословсько охарактеризовано принuзип Таліону, виявлено деякі проблемні моменти в иілісному розумінні даного принщипу та запропоновано конщепиію прямого взаємозв'язку між основними принципами формування $і$ застосування єврейського права в біблійний період. Останнє й взяло на себе функиію наукової новизни иьього дослідження, показало максимально тісний взаємозв'язок $i$ корелячію, щуо, своєю чергою, дало можливість иілісно поглянути на певні проблеми і задати правильний алгоритм для подальших досліджень названої тематики.

Ключові слова: принщип Таліону, принципи єврейського права, виховний принцип, єврейське право, біблійне право, богослів'я.

Питання правозастосування - це завжди питання оцінки конкретної ситуації і прийняття рішення щодо осіб, які беруть участь у ній. Тора - не виняток. Але тут ніколи (у всякому разі, щодо суду

(C) Франків Дмитро, 2020 
людського) не йдеться про винуватість чи невинуватість людини взагалі. Оцінюється не людина як така, а лише конкретний здійснений нею вчинок; оцінка ж людини в цілому - справа суду Божого, який Бог вершить Сам, не передоручаючи нікому. Така остаточна оцінка людини на відповідність Торі називається єврейським словом тי, яке перекладається зазвичай як «суд», як кваліфікація злочину. Кваліфікацію життя людини в цілому дає на Своєму суді Бог; людині ж надано право кваліфікації конкретних вчинків, для чого їй і дана Тора. При цьому важливо мати на увазі, що кваліфікація ця пов'язана не тільки із судочинством як таким. Дотримання Тори передбачає такого ж роду оцінку людиною будь-якого свого вчинку і кожного прийнятого нею рішення, тому що духовне життя людини і визначається, власне, зробленим в тій чи іншій ситуації вибором і прийнятим рішенням. Нерідко це стосується не лише власних вчинків, а й вчинків інших людей, щодо яких потрібно визначитись: можна їх підтримати чи ні. Людському суду надається право на визначення місця лише конкретного вчинку або злочину. Покарання або відплата - не самоціль: до помсти Тора в принципі ставиться негативно, обмежено допускаючи ії тільки тому, що вона була передбачена звичаєвим правом; покарання ж саме по собі не було головною метою, адже не гарантувало подолання наслідків скоєного злочину. Взагалі, пропоновані Торою санкції за злочини, якщо їх і можна назвати покаранням, то в дуже специфічному сенсі. Тора взагалі немислима поза контекстом відносин людини з Богом, а всякий переступ розглядається нею як наслідок порушення або повного руйнування цих відносин, яке тягне за собою і руйнування відносин з ближніми. Головною метою пропонованих Торою санкцій стає відновлення втрачених стосунків, перш за все з Богом, а потім і з ближніми. Тора не карає людину за злочини, а допомагає подолати їх наслідки, оскільки вони можливі до подолання. Тим самим Тора допомагає людині відновити ту духовну якість свого життя, яка дасть ій можливість пройти Божий суд 3 найменшими втратами. Власне, в такому річищі ми і розглядатимемо проблему основного принципу застосування єврейського права біблійного періоду - принципу Таліону.

Серед науковців, які досліджували подібну проблематику, відзначимо А. Гедалію, А. Б. Волкова, Е. Е. Урбаха, Х. Н. Бяліка, 138 
Р. А. Штейнзальца, М. Пантелята, М. Грінберга, М. Елона, А. Барака, Т. Гідроі, С. Гольдштсппа, Н. Лерпера, К. Кляйна, Л. Ліховскі, М. Маутнера, А. М. Рабелло, І. Енгларда, У. Ядіна, Л. Шифмана, С. М. Пілкінгтона, І. Б. Левнера, Л. Фінкелстайна, Джона Д. Клієра, М. Еліаде, К. Блейкслі, М. Богдана, П. Глеіпа, Р. Давида, І. Кастеллуччі, Х. Кьотна, Дж. Меррімапа, Е. Орюджю, В. Палмера, Ж. дю Плессі, К. Рида, У. Тетлі, Р. Циммерманна, К. Цвайгерта, П. Гленна, М. Марченка, М. Елона, С. Місевича, В. Беспалька, А. Лопухіна, Г. Пікова, А. Даніеляна, С. Слободнюка, Н. Яковенка та ін. Усі названі дослідники розглядали принцип Таліону більшою чи меншою мірою, втім у заданій нами проблематиці, наскільки нам відомо, тема розглянута ще не була.

Новизна цього дослідження полягає у тому, що ми поєднали і провели прямий взаємозв'язок між двома основними принципами єврейського права, а саме - принципом Таліону (основним принципом дії у біблійному праві) та виховним принципом (на нашу думку, основним принципом формування того самого права). Що дало можливість не лише побачити пряму кореляцію таких принципів і максимально тісний взаємозв'язок, а й показати, що принцип Таліону є вираженням і проекцією вихідного та формотворчого принципу єврейського права - виховного, причому не як санкційний, а саме як морально-виховний.

Таким чином, метою дослідження стає феномен біблійного принципу Таліону, специфіка його застосування та його богословська рефлексія, внутрішня логіка і зовнішні суперечності цього принципу, співвідношення з основним принципом формування єврейського права і виявлення закономірностей і богословських взаємозв'язків.

Принцип рівної відплати (принцип Таліону) відомий як принцип «око за око». Ось його формула в тексті: «Хто зробить ваду своєму ближньому, як повинно зробити те ж, що він зробив: перелом за перелом, око за око, зуб за зуб; як він зробив пошкодження на тілі людини, так і йому має зробити. А хто заб'є скотину, той відшкодує іiі, а хто заб'є людину, той буде забитий» (Лев. 24: 19-21). У книзі Вихід про це сказано так: «А якщо станеться нещастя, то даси душу за душу, око за око, зуб за зуб, руку за руку, ногу за ногу, обпалених за обпалених, рану за рану, забій 
за забій» (Вих. 21: 23-25). Такими є вимоги до відшкодування шкоди для одноплемінників і людей вільних [4, с. 36]. Для рабів позначався інший тариф: «Якщо хто раба свого вдарить в око, або в око невільниці своєї, і знищить його, той на волю відпустить його за око його. А якщо виб'є зуб раба свого, або зуб невільниці своєї, нехай відпустить їх на волю за зуб» (Вих. 21: 26-27). Цей принцип отримував розвиток у межах біблійного права фактично всюди. Наприклад, брехливий свідок повинен був нести таку саму відповідальність, яка покладалась на обвинуваченого (Втор 19: 16-20) і так далі [7, с. 62].

Звернемо увагу спочатку на досить велику близькість між Біблією та законами Хаммурапі, де також сформульований своєрідний принцип Таліону (згідно з цим принципом рівної відплати, покарання дзеркально відображає злочин): «Якщо син ударив свого батька, йому повинні відрубати руку. Якщо людина виколола око чиємусь синові, повинні виколоти їй око. Якщо вона переломила кістку людині, повинні переломити їй кістку... Якщо людина вибила зуб людині, рівній їй, повинні вибити їй зуб» (закони Хаммурапі, п. 195-197, 200). Неможливо не побачити, що закони Хаммурапі справді близькі до законів П'ятикнижжя за змістом і фразеологією [15, с. 38-39]. Шукаючи пояснення цьому, богослів'я вивело наступне. Так, Б. А. Тураєв писав: «Деякі збіги Біблії і вавилонського законодавства можна пояснити свого роду рецепцією вавилонського права ще в глибоку давнину в Палестині, в той час, коли вона входила в зону впливу імперії Хаммурапі. Сімейні стосунки єврейських патріархів - найкращий коментар до законів Хаммурапі. Можна сказати, що й Авраам, і Яків, і Лаван жили по вавилонському праву» [14, с. 112]. Книга Буття свідчить про те, що єврейські предки жили в суспільному середовищі, в якому діяли норми стародавнього месопотамського законодавства [1]. Причому розстановка цінностей у Синайському законодавстві така: життя важливіше власності, життя і матеріальне майно не можна порівняти, на відміну від законів Хаммурапі, які ставлять інші пріоритети [11, с. 73]. Між біблійним законодавством і месопотамськими законами існує й інша відмінність у використанні принципу Таліону. У клинописному законодавстві принцип Таліону іноді призводить до заміщення покарання. Наприклад, 230-й пункт законів Хамму140

H.Skovoroda Institute of Philosophy of the NAS of Ukraine 
рапі свідчить, що якщо будинок, побудований будівельником, впаде і вб'є сина господаря, то син будівельника повинен бути страчений. Винність батька в даному випадку переходить на невинного сина. У біблійному праві замісне покарання за кримінальні злочини практично виключається. Прикладом може служити постанова про буцливого вола [1, с. 104-119], згідно з якою господарю вола може бути залишене життя. А Второзаконня $(24,16)$ зовсім виключає замісне покарання: «Батьки не повинні бути покарані смертю за дітей, а діти не будуть покарані за батьків; кожен за гріх свій смертю покараний буде». Утім, цьому начебто суперечить Втор. 5,9 і Вих. 20, 5, де зображений Бог, що карає за провину батьків до третього і четвертого роду. Проте, згідно з М. Грінбергом, ця суперечність знімається тим, що біблійне законодавство, на відміну від небіблійного, ніколи не карає колективно або шляхом заміщення кримінального злочину, оскільки при покаранні у зв'язку з кримінальними злочинами в Біблії діє тільки принцип особистої відповідальності. У Біблії ми зустрічаємося і з колективним, або замісним покаранням, яке відноситься до релігійних злочинів - тих, які безпосередньо ображають Бога (Іс Нав. 7; 2 Цар. 21; Суд. 21) [5, с. 220-227]. «Уявлення про те, що Бог може покласти відповідальність і вину на всю сім'ю людини і її нащадків, біблійний Ізраїль поділяв зі своїми сусідами. Унікальною була віра Ізраїлю, що виключне право на таке рішення належало Богові; узурпуючи цю божественну прерогативу, людина скоювала зухвале беззаконня», - підводить підсумок М. Грінберг [5, с. 226]. Так що для пояснення зовнішніх суперечностей біблійного законодавства не завжди слід вдаватися лише до літературно-критичного методу та уявлення про правовідносини як про історичну еволюцію біблійного права, а певні вдавані суперечності можна пояснити, користуючись богословськими методами цілісного аналізу [1]. I неважко переконатися, що логіка імплементації однієї й тієї самої ціннісної системи в певних випадках різниться, і починає прояснятись, лише якщо розуміти глибину принципу дії $\mathrm{i}$ взаємозв'язок з принципами формування.

Також ми бачимо відмінність у досліджуваному нами принципі залежно від різних Книг Біблії. Так, порушення вірності Богу Книга Второзаконня пропонує в будь-якому разі карати смертною карою (Втор. 13). Законодавство Книги Виходу можна вважати в 
цьому випадку менш жорстким: воно передбачає накладення ритуальної заборони («херему») на відступника (Вих. 22: 20), яке не обов'язково тягнуло за собою смертну кару (могло обмежитись вигнанням). Коли ж справа стосується справедливості, легко помітити, що Книга Виходу пропонує нам більш-менш універсальний підхід, який якраз заснований на принципі Таліону. Тоді як у Книзі Второзаконня принцип Таліону не проглядається так явно, як у Книзі Виходу. Тут, зокрема, з'являються покарання тілесні (Втор. 25: 1-3), причому сфера застосування їх чітко не визначена. Водночас, у системі прецедентного права (а старозавітне законодавство є прикладом саме прецедентного права) для формування правничої практики досить було одних судових визначень [13, с. 202-203]. Однак для нас важливо інше: у рамках логіки, заданої принципом Таліону, такі покарання мають сенс лише у випадку правильних акцентів принципів формування (виховного) і дії (рівноцінної відповідальності). Разом $з$ тим, такі принципи приводять нас до пошуку в будь-яких нормах, заповідях і навіть принципах першою чергою наміру вчинків і наміру самих заповідей.

У Законах Мойсея передбачається пошук намірів, керуючись якими був вчинений той чи інший злочин. Наприклад, якщо в полі буде знайдено людину, невідомо ким вбиту, приписи Мойсеєвого закону такі: «Якщо буде знайдений вбитий, який лежить на полі, i невідомо хто вбив його, і нехай вийдуть старійшини твої і судді твої і виміряють відстань до міст, які навколо вбитого. I старійшини міста того, яке буде найближче до вбитого, хай візьмуть телицю, відведуть в пустелю, заколють ії там і омиють руки свої над головою телиці, свідчачи цим свою невинність у вбивстві» (Вт. 21: 1-8). Подібне можемо побачити й на іншому прикладі. Серед заповідей Декалогу є вимога «не вбий». Далі, однак, коли починається конкретика кримінальних відносин, ми знаходимо норми Таліону, які санкціонують вбивство (життя за життя), і також говориться, коли і як слід замінити вбивство викупом. Якщо зіставити категоричне «не вбий» 3 Декалогу з Таліоном в його кримінальній частині, то нескладно помітити, що Декалог становить правову основу логіки практичного законодавства, задає гуманістичну перспективу останнього [7]. Тому вчинене такою людиною вбивство довелось би вважати вбивством ненавмисним, за яке Тора за142

H.Skovoroda Institute of Philosophy of the NAS of Ukraine 
повідає інше покарання, ніж за вбивство умисне (Вих. 21: 12-14). Аналогічним чином, наприклад, гіпотетична крадіжка була б підставою вимагати компенсації вартості викраденого майна, але не в кратному розмірі, як того вимагає Тора в звичайному випадку (Вих. 21: 1-6), адже кратний розмір компенсації в даному випадку передбачає також і відшкодування моральної шкоди, про розмір якої гіпотетичний злочинець знати ніяк не може. Але саме незнання цих заповідей їх порушником не може бути підставою для пом'якшення покарання, адже йдеться не лише про його власні відносини з Богом чи про його стосунки з іншими людьми, а й про порушення ним справедливості по відношенню до ближнього, яке стосується вже не лише самого порушника, а й інших людей. Принцип простий: вчинений людиною гріх, що стосується лише іiі, залишається на розсуд Бога і суду Божого. Якщо ж гріх або його наслідки поширюються на ближнього, то гріх стає вже не просто гріхом, але злочином, за який грішника, що став злочинцем, можна вже судити судом людським, звісно ж, у суворій відповідності до Тори [13, с. 197]. Випадок гіпотетичної нічної крадіжки в книзі Вихід розглядається більш детально. Вбивство нічного злодія не ставиться в провину тому, хто вбив, а вбивство денного злодія тягне за собою відповідальність (Вих. 22, 2-3) [5, с. 228]. Також бралися до уваги, крім наміру, також необережність і випадковість. Винними у випадковому вбивстві пропонувалося мати на увазі три міста, де злочинці могли ховатися від кровної помсти (Втор. 19: 16). Вбивство нічного злодія на місці злочину можна вважати стародавнім різновидом необхідної оборони. Винний у сварці з каліцтвом у стані сильного душевного хвилювання зобов'язувався до «плати за зупинку в роботі» і відшкодування витрат на лікування (Вихід, 21:19). У законах про покарання за вбивство розрізняють вбивство з наміром (воно тягне засудження винного до смерті) i без злого наміру - в цьому випадку вбивця може бігти в укриття (до жертовника) [4, с. 40].

Усе це ілюструє, що справжня причина такого принципу дії, як принцип Таліону, не просто знаходиться в тісному взаємозв'язку 3 основним принципом формування - виховним, що робить ці принципи єдиним цілим, а навіть більше - шукає у вчинках наміри, вчить ці наміри бачити і розуміти. 
Попри пошук намірів вчинення злочину та толерації [3, с. 3], принцип Таліону був, безперечно, жорстоким у своєму застосуванні. Законодавство Мойсея також карає смертю перелюб (Втор. 22, 22), згвалтування зарученої (Втор. 22, 23-25) і викрадення будь-якого ізраїльтянина (Вих. 21, 16). Можна навести ще кілька прикладів, пов'язаних зі смертною карою (фізичним знищенням порушників). Так, повинен знищуватися з народу Ізраїлю, за Торою, той, хто самовільно помажеться миром, призначеним для священиків, нащадків Аарона (Вих. 30:33), або буде вживати жертовне м'ясо, будучи ритуально нечистим (Лев. 7: 20-21), жир жертовних тварин (Лев. 7:25), кров будь-якої тварини (Лев. 7: 27, 17:14 Лев. 7: 27, 17:14). Також усі ізраїльтяни повинні були всю худобу приносити в жертву Всевишньому, щоб жир ії був спалений священником, при цьому всі жертви повинні приноситись у скинії, а не десь в іншому місці, і не приведи Господь, іншому божеству (Лев. 17). За порушення цього - смерть. Не можна їсти жертовне м'ясо на третій день, а спалити його (Лев. 19:8), знов таки, за порушення - смерть. Взагалі, карається смертю всяке осквернення святині (Лев. 22:3), недотримання загального посту (Лев. 23:29), не вчинення Пасхи без поважних причин (Числ. 9:13). Смертю каралося богохульство, якщо хто в ньому був помічений (Лев. 24:14). Це те, що стосується порушення ритуальної чистоти. У тому, що стосується соціальних норм, за принципом таліону, вбивство каралося смертю (Лев. 24:17, 21, Числ. 35:31). Так само заборонені під страхом смерті всі види інцесту, секс $з$ дружиною під час іiі ритуальної нечистоти, скотоложство, гомосексуалізм - все в одному ряду (див. Лев., Гл. 20). Наречена, яка не була дівчиною до моменту весілля, заміжня жінка, яка, коли іiі гвалтували, не кричала, сам насильник, - також мали бути вбиті (Вт. 22 гл.). Смертю також карається непокора батькам (Вт. 21: 18-21). Взагалі, все, що стосується сфери відтворення, пов'язане з жорсткою нормою [10, с. 135]. Дуже точно вловлює цей момент і озвучує його В. С. Нерсесянц. За своєю правовою суттю, пише він, «смертна кара за умисне вбивство це вираження і підтвердження сили права і правового принципу рівноцінної відповідальності в тому крайньому випадку протиправних дій, коли порушується вихідна і головна заборона права заборона вбивати. Наявність такого необхідного і справедливого 144

H.Skovoroda Institute of Philosophy of the NAS of Ukraine 
співвідношення між вищою санкцією і основною забороною права має фундаментальне значення для всієї системи правових заборон $\mathrm{i}$ відповідних санкцій. Звідси зрозуміло, що скасування смертної кари за умисне вбивство - це не проста заміна однієї санкції іншою, а відмова від принципу права і рівноцінної правової відповідальності в найважливішому і найнапруженішому пункті правового регулювання взагалі» [6, с. 629; 8, с. 472]. На що піти в певних моментах, вирішальних для виховання цілого народу, означало би зрадити ці основні принципи.

Не таке суворе законодавство Книги Второзаконня було розраховане на соціум, де існував консенсус і щодо ціннісної системи, і щодо загальноприйнятих поведінкових моделей [9, с. 296]. I саме воно повністю задіює відповідні, цілком налагоджені суспільнопсихологічні механізми: закон вимагає від злочинця лише дії, такої дії, яка сама по собі стала б свідченням визнання порушення ним норми закону. Ніякого «виправлення та каяття» в тому сенсі, в якому про них говорять, маючи на увазі сучасну пенітенціарну систему, тут немає. Такий підхід на перший погляд може видатись дещо формальним, однак слід мати на увазі, що в невеликих сільських громадах (з яких у додержавний період складався єврейський соціум) сплачений злочинцем штраф ставав доходом громади, а загальне осудження в такому випадку ставало само собою зрозумілим. Передбачалося, що цього буде достатньо, щоб той, хто вчинив злочин, переосмислив свій вчинок; якщо ж скоєно було щось непоправне, наприклад, вбивство або відступництво, злочинця або страчували, або виганяли. Але навіть смертна кара за умисне вбивство не мала в даному випадку мети залякування або чогось подібного. У книзі Второзаконня на перший план виходить саме усвідомлення злочинцем своєї провини. Не випадково в цій книзі стільки уваги приділяється навчанню народу (як дорослих, так і дітей) Торі (Втор. 6: 1-9). Тому і з'являється такий вид покарання, як покарання тілесне, яке має сенс лише в тому випадку, якщо злочинця хочуть змусити не так відшкодувати завдані ним збитки, як замислитися над скоєним. 3 одного боку, такий підхід засвідчує більш глибоке моральне осмислення тих гріхів і злочинів, які раніше розглядалися лише як порушення загальноприйнятої поведінкової норми; а 3 іншого - осмислення це відбувається переважно, якщо не ви- 
ключно, у формі релігійній, а саме - у вигляді правил ритуальної чистоти [13, с. 204-205, 300].

Отже, внутрішня логіка застосування принципу Таліону знаходиться в прямій кореляціії з виховним принципом і $є$ фактично проекцією виховного мотиву на буденну реальність. I, на нашу думку, лише таке розуміння цих двох принципів в їх внутрішній зв'язці і поєднанні дає можливість вирішити певні, на перший погляд суперечливі, моменти. Це стосується проблеми співвідношення в межах принципу Таліону приписів смертної кари і непорушного припису Декалогу «не вбий», а також присутності в різних біблійних книгах, де спрацьовує принцип Таліону, відмінності між жорсткою і м'якою реакцією. Також важлива для богослів'я єврейського права проблема певної схожості між біблійним принципом Таліону та подібним принципом у законах Хаммурапі. Усі ці проблеми були висвітлені в нашій статті, зведені в цілісну концепцію та поданий алгоритм їх вирішення засобом запропонованої нами концепції максимально-тісного взаємозв'язку між застосувальним принципом Таліону та формотворчим виховним принципом, який являє собою проекцію в площину використання на практиці цього основного принципу єврейського права.

\section{ЛITЕРАТУРА}

1. Акимов В. В. Правовые памятники древней Месопотамии и Библия. Труды Киевской Духовной Академии. 2006. № 4. С. 104-119.

2. Беспалько В. Г. Принцип Талиона в Моисеевом уголовном законодательстве. Вестник КГУ им. Н.А. Некрасова. 2016. № 2. С. 277-280.

3. Гараджа В. И. Толерантность и религиозная нетерпимость. Философские науки. 2004. № 3. С. 18-32.

4. Графский В. Г. Пятикнижие Моисея в истории права и правоведения. Философия права Пятикнижсия. Москва: Изд-во «ЛУМ», 2012. C. 31-47.

5. Гринберг М. Некоторые постулаты библейского уголовного права. Библейские исследования: Сборник статей / пер. с англ. Т. И. Подолской. М. : The international Center for University Teaching of Jewish Civilization under the auspices of the President of Israel; Центр славяноиудаистских исследований, Институт Славяноведения и Балканистики РАН; Центр «Сэфер», 1997. С. 205-232. 
6. Гусейнов А. А. Великие моралисты. (2-е изд., доп.). М. : Республика, $1995.351 \mathrm{c.}$

7. Гусейнов А. А. Десятисловие Моисея: канон справедливости. Философия права Пятикнижсия. Москва : Изд-во «ЛУМ», 2012. С. 47-70.

8. Лапаева В. В. Соотношение права и морали как философскоправовая проблема. Философия права Пятикнижсия. Москва: Изд-во «ЛУМ», 2012. С. 468-484.

9. Лафитский В. И. Этюды о книгах Ветхого Завета. Философия права Пятикнижия. Москва : Изд-во «ЛУМ», 2012. С. 289-320.

10. Матушанская Ю. Г. Толерантность и интолерантность в Танахе и Новом Завете. Научные труды по иудаике. Материаль ХVII Международной ежегодной конференции по иудаике. Том 1. Москва : Центр «Сэфэр» (Академическая серия. Вып. 30), 2010. С. 130-140.

11. Нефедов М. Сходства и различия между книгой Завета (Исх. 21$23)$ и законами Хаммурапи. Христианское чтение. 2015. № 5. С. 70-81.

12. Слободнюк С. Л. Справедливость бытия и принцип Талиона: опыт типологии права. Вестник Красноярского государственного педагогического университета им. В. П. Астафьева. 2014. № 4 (30). С. 23-32.

13. Сорокин В. Тора: пространство правовое и пространство духовное. Философия права Пятикнижия. Москва: Изд-во «ЛУМ», 2012. C. $178-220$. $321 \mathrm{c}$.

14. Тураев Б. А. История Древнего Востока. Минск : Харвест, 2002.

15. Шиффман Л. От текста к традиции: история иудаизма в эпоху Второго храма и период Мишны и Талмуда. Москва: Мосты культуры, GESHARIM, 2016. 304 c.

16. Яковенко Н. С. Общий анализ принципа Талиона и его отражение в ранних источниках законотворчества. Право и Государство: теория и практика. 2010. № 8 (68). С. 138-141.

17. Brueggemann Walter. Deuteronomy (Abingdon Old Testament Commentaries). Nashville, TN : Abingdon, 2001. 352 p.

18. Clooney Francis X. S.J. Comparative Theology: Deep Learning Across Religious Borders. Wiley-Blackwell, 2010. 194 p.

19. Falk Zeev W. Hebrew Law in Biblical Times: An Introduction. Neal A. Maxwell Institute for Religious Scholarship; 2 edition, 2001. 241 p.

20. Fleming D. The Biblical tradition of anointing priests. Journal of Biblical Literature. 1998. Vol. 117. P. 401-414.

21. Glenn H. Patrick. Legal Traditions of the World: Sustainable diversity in law. Oxford University Press; Fifth edition, 2014. 456 p. 
22. Glenn H. Patrick. Legal Traditions of the World. New York, Oxford : Oxford University Press; Second Edition, 2004. P. 432.

23. Göran L. Bound for freedom: the Book of Exodus in Jewish and Christian traditions. New York : Hendrickson Publishers, 1999. 334 p.

24. Harris J. W. Legal philosophies. Oxford University Press; 2 edition. 2005. $332 \mathrm{p}$.

25. Macy J. The Rule of Law and the Rule of Wisdom: in Plato, al-Farabi and Maimonides. Studies in Muslim-Jewish Relations. Vol. 1. Harwood, 1994. P. 205-232.

26. McDonald L.M. The Formation of the Biblical Canon. London: Bloomsbury T\&T Clark, 2017. 1029 p.

27. McLeod I. Legal Theory. London : Red Globe Press; 6th ed., 2012. $260 \mathrm{p}$.

28. Yadin U. From Picemeal Legislation to a Modern Code, The Israeli Expirience. Memoriam Uri Yadin. Jerusalem, 1990. Vol. II. 363 p.

29. Zaprometova O. The Symbol of Torah as Wisdom and Light reflected in Eastern European Culture. The Influence of Jewish Culture on the Intellectual Heritage of Central and Eastern Europe. Humanitas. Studia Kulturoznawcze. Krakow, 2011. P. 137-146.

\section{REFERENCES}

Akimov, V. V. (2006). Legal Monuments of Ancient Mesopotamia and the Bible. Trudy Kievskoj Duhovnoj Akademii (Proceedings of the Kiev Theological Academy), 4, 104-119. [In Russian].

Bespal'ko, V. G. (2016). Talion's Principle in the Mosaic Criminal Law. Vestnik KGU im. N.A. Nekrasova (Bulletin of KSU named N.A. Nekrasov), 2, 277-280. [In Russian].

Garadzha, V. I. (2004). Tolerance and religious intolerance. Filosofskie nauki (Philosophical Sciences), 3, 18-32. [In Russian].

Grafskij, V. G. (2012). The Pentateuch of Moses in the History of Law and Jurisprudence. Filosofija prava Pjatiknizhija (Philosophy of Law of the Pentateuch). Moscow: Izd-vo "LUM". P. 31-47. [In Russian].

Grinberg, M. (1997). Some Biblical Criminal Law Postulates. Biblejskie issledovanija: Sbornik statej (Bible Studies: Collection of Articles). Podolskay, T. I. (Transl.). Moscow: The international Center for University Teaching of Jewish Civilization under the auspices of the President of Israel; Centr slavjano- 
iudaistskih issledovanij, Institut Slavjanovedenija i Balkanistiki RAN; Centr «Sjefer», P. 205-232. [In Russian].

Gusejnov, A. A. (1995). Great moralists. (2-e izd., dop.). Moscow: Respublika, 351 p. [In Russian].

Gusejnov, A. A. (2012). The Decalogue of Moses: The Canon of Justice. Filosofija prava Pjatiknizhija (Philosophy of Law of the Pentateuch). Moscow: Izd-vo "LUM", P. 47-70. [In Russian].

Lapaeva, V. V. (2012). Correlation of law and morality as a philosophical and legal problem. Filosofija prava Pjatiknizhija (Philosophy of Law of the Pentateuch). Moscow: Izd-vo "LUM", P. 468-484. [In Russian].

Lafitskij, V. I. (2012). Studies in Old Testament Books. Filosofija prava Pjatiknizhija (Philosophy of Law of the Pentateuch). Moscow: Izd-vo "LUM", P. 289-320. [In Russian].

Matushanskaja, Ju. G. (2010). Tolerance and Intolerance in the Tanach and New Testament. Nauchnye trudy po iudaike. Materialy XVII Mezhdunarodnoj ezhegodnoj konferencii po iudaike (Scientific works on Judaica. Materials of the XVII International annual conference on Jewish studies). Tom 1. Moscow: Centr "Sjefjer" (Akademicheskaja serija. Vyp. 30), P. 130-140. [In Russian].

Nefedov, M. (2015). Similarities and Differences between the Book of the Covenant (Exodus 21-23) and the Laws of Hammurabi. Hristianskoe chtenie (Christian reading), 5, 70-81. [In Russian].

Slobodnjuk, S. L. (2014). The justice of being and the principle of Talion: the experience of the typology of law. Vestnik Krasnojarskogo gosudarstvennogo pedagogicheskogo universiteta im. V. P. Astaf'eva (Bulletin of the Krasnoyarsk State Pedagogical University. V. P. Astafieva), 4(30), 23-32. [In Russian].

Sorokin, V. (2012). Torah: legal space and spiritual space. Filosofija prava Pjatiknizhija (Philosophy of Law of the Pentateuch). Moscow: Izd-vo "LUM". P. 178-220. [In Russian].

Turaev, B. A. (2002). History of the Ancient East. Minsk: Harvest. 321 p. [In Russian].

Shiffman L. (2016). From text to tradition: the history of Judaism in the era of the Second Temple and the period of the Mishnah and Talmud. Moscow: Mosty kul'tury, GESHARIM, 304 p. [In Russian]. 
Jakovenko, N. S. (2010). General analysis of the Talion principle and its reflection in the early sources of lawmaking. Pravo i Gosudarstvo: teorija i praktika (Law and State: theory and practice), 8(68), 138-141. [In Russian].

Brueggemann Walter. (2001). Deuteronomy (Abingdon Old Testament Commentaries). Nashville, TN: Abingdon. $352 \mathrm{p}$.

Clooney, Francis X. SJ. (2010). Comparative Theology: Deep Learning Across Religious Borders. Wiley-Blackwell. 194 p.

Falk, Zeev W. (2001). Hebrew Law in Biblical Times: An Introduction. Neal A. Maxwell Institute for Religious Scholarship; 2 edition. 241 p.

Fleming, D. (1998). The Biblical tradition of anointing priests. Journal of Biblical Literature. Vol. 117. P. 401-414.

Glenn, H. Patrick. (2014). Legal Traditions of the World: Sustainable diversity in law. Oxford University Press; Fifth edition. 456 p.

Glenn, H. Patrick. (2004). Legal Traditions of the World. New York, Oxford: Oxford University Press; Second Edition, 432 p.

Göran, L. (1999). Bound for freedom: the Book of Exodus in Jewish and Christian traditions. New York: Hendrickson Publishers. 334 p.

Harris, J. W. (2005). Legal philosophies. Oxford University Press; 2 edition. $332 \mathrm{p}$.

Macy, J. (1994). The Rule of Law and the Rule of Wisdom: in Plato, al-Farabi and Maimonides. Studies in Muslim-Jewish Relations. Vol. 1. Harwood. P. 205232.

McDonald, L.M. (2017). The Formation of the Biblical Canon. London: Bloomsbury T\&T Clark, 1029 p.

McLeod, I. (2012). Legal Theory. London: Red Globe Press; 6th ed. 260 p.

Yadin, U. (1990). From Picemeal Legislation to a Modern Code, The Israeli Expirience. Memoriam Uri Yadin. Jerusalem, Vol. II. 363 p.

Zaprometova, O. (2011). The Symbol of Torah as Wisdom and Light reflected in Eastern European Culture. The Influence of Jewish Culture on the Intellectual Heritage of Central and Eastern Europe. Humanitas. Studia Kulturoznawcze. Krakow, P. 137-146. 


\section{hieromonk Dmytro (Frankiv)}

Postgraduate student, Department of Theology and Religious Studies, National Pedagogical Dragomanov University; Kyiv, Ukraine; e-mail: ieromonahdmytro@gmail.com; ORCID: https://orcid.org/0000-0002-2342-0951

\section{The theological analysis of the Talion principle and its correlation with the original principle of formation of Jewish law in the Biblical Era}

\section{Abstract}

The purpose of this article was to investigate the Talion principle as the basic principle of Jewish law. As a result of the study, the Talion principle was theologically characterized, some of the problematic issues in a holistic understanding of the principle were identified, the conception of a direct relationship between the basic principles of the formation and application of Jewish law during the biblical period was proposed. The latter took on the function of scientific novelty of this study, showed the closest possible connection and correlation which allowed us to take a holistic look at certain problems and to set the right algorithm for further research of the subject. Thus, the internal logic of applying the Talion principle is in fact a projection of an educational motive on everyday reality. In our opinion, only such understanding of these two principles in their interconnection and combination allows us to resolve some certain points which seems to be contradictory. For example, this applies to the problem of the ratio within the Talion principle of the death penalty and the unbroken injunction of the Decalogue "do not kill", as well as the presence of the difference between hard and soft reactions to certain crimes which are often the same in the various biblical books in which the Talion principle works. In our study we were able to consider and propose a solution to the problem of a certain similarity between the Biblical principle of Talion and a similar principle in the laws of Hammurabi. All these problems were covered in our article, summarized in a holistic concept and an algorithm for their solution was presented. It also showed that the true cause of such a principle of biblical law as the principle of Talion is not simply in close connection with the basic principle of formation - the educational which makes these principles one whole. Moreover, it seeks intentions in actions, teaches to see and understand these intentions, that is, it is not only a projection and reflection, but also a means of an educational principle that educates in the right direction (divine) the representative of biblical Israel as well as us - the inhabitants of the 21st century.

Keywords: Talion principle, Jewish law principles, educational principle, Jewish law, biblical law, theology. 